\title{
APPLICATION OF REAL-METHODIC FOR MASTERING ARM WRESTLING TECHNIQUES
}

Bezkorovainyi D.A.

Kharkiv National University of Municipal Economy

\begin{abstract}
Purpose: to substantiate application of REAL-methodic for training of students-sportsmen at initial stage of arm wrestling. Material: in the research $251^{\text {st }}$ and $2^{\text {nd }}$ year students participated. The students attended 3 trainings every week. Each training session lasted 2 hours. REAL-methodic was used at initial stage of training at the beginning of the first semester and after one month of trainings. The research took two months (September October 2015). At each training session REAL-methodic used three times: in first part (warming up); in second (main) - in rest pauses for understanding of discipline; in third part (final) for recreation and relaxation. Results: 23 from 25 students-sportsmen accurately fulfilled two main arm wrestling techniques: attack over top and attack in hook; two sportsmen made little mistakes in attacking techniques. It was found that effectiveness of this methodic application to large extent depends on students' motivation, on comfort condition of their nervous system; on presence of mutual trust and positive micro-climate in students' group. Conclusions: application of REAL-methodic at initial stage of students-sportsmen's training accelerated perception of training technologies and arm wrestling techniques, shortened period of techniques' mastering, permitted to quicker pass to preparatory period of sport training basic stage.
\end{abstract}

Key words: arm wrestling, sport training, REAL-methodic, schema, pattern.

\section{Introduction}

Arm wrestling is a traumatic kind of sports due to its power orientation and technical complexity. That is why it is extremely dangerous to admit students-sportsmen to competition functioning without their clear understanding of arm wrestling techniques. When mastering techniques at initial training stage there appears some difficulties. The main difficulty for young sportsmen is perception, systemizing, processing and reproduction of verbal and motor (non verbal) information, rendered by coach. This difficulty can be solved with the help of REAL-methodic, offered by N.M. Maslova and her followers [5, 9-13].

Health related component of REAL-methodic completely justifies itself if it is used in physical culture sport sphere. It protects, corrects and improves health due to starting of self regulation mechanism [15]. General approaches to determination of purpose, tasks and content of environmental pedagogic, including physical education means, are elucidated in monograph of Prof. L.N. Necheporenko [16]. In work by N.A. Oleynik et al. [17] content of discipline "Physical culture" was analyzed from environmental position and correspondence to conception of noosphere education. The authors present all groups of means and methods of psycho-physical selfregulation, which are used in students' physical education. The authors note that specificity of most of kinds of sports implies usage of right-side and left side movements. That is why specialists in physical culture and sports shall understand it by themselves, feel it and promote it among supporters of noosphere education. In work by N.N. Zavidivska [6] noosphere pedagogic paradigm was substantiated as conceptual basis of students' healthrelated physical culture education. The author reveals noosphere essence of physical education and health related education of students as well as generalizes main aspects of noosphere pedagogic paradigm oriented on fundamentalization of health related physical culture education. In this work the following necessities are noted: cultivation of holistic, sound thinking; provisioning of person with tools for independent practicing of healthy life style. Besides, ability to set aims, to choose physical culture means and foresee after effects of own actions in health are marked out.

In the works by V.M. Klochko and D.O. Bezkorovayniy [8], V.M. Klochko and T.V. Bondarenko [11] it is noted that application of REAL-methodic at initial stage of students-sportsmen's training in arm wrestling gives positive result, accelerates perception of training technologies and arm wrestling techniques, shortens period of techniques' mastering as well as speeds up transition to preparatory basic stage of sport training [8, 11]. Alongside with it there is a demand in continuation of such researches for prevention from traumatism in arm wrestling.

Purpose, tasks of the work, material and methods

The purpose of the work is to substantiate application of REAL-methodic for training of studentssportsmen at initial stage of arm wrestling during their studying in HEE of engineering specialties.

The tasks of the work: 1) to study literature on the researched problem; 2) to work out schema-pattern of sportsman's skillfulness; 3 ) to substantiate purposefulness of application of the worked out schema-pattern in the process of training session.

Material and methods of the research: in the research $1^{\text {st }}$ and $2^{\text {nd }}$ year students of KhNUME participated $(n=25)$. Students attended trainings three times every week. Each training session lasted 2 hours. REAL-methodic

(C) Bezkorovainyi D.A., 2015

http://dx.doi.org/10.15561/20755279.2015.0502 
was used at initial stage of training at the beginning of the first semester and after one month of trainings. From that moment student received initial idea about this kind of sports, about elements of sportsmanship, familiarized with principles of techniques and tactic of duel.

The research took two months (September - October 2015). At each training session REAL-methodic used three times: in first part (warming up); in second (main) - in rest pauses for understanding of discipline; in third part (final) for recreation and relaxation.

At the end of the research sportsmen's fulfillment of techniques was assessed by experts. It was noted that 23 from 25 students-sportsmen accurately fulfilled two main arm wrestling techniques: attack over top and attack in hook; two sportsmen made little mistakes in attacking techniques.

\section{Results of the researches}

Arm wrestling is a power kind of sports, in which important role is played by technical tactic fitness of sportsmen. By the latter arm wrestling is very close to wrestling. Arm wrestling is full fledged and attractive kind of sports with well developed system of trainings and competitions. Initial stage is of special importance for a sportsman. In arm wrestling one must not start main training loads and direct duels without proper technical training. Traumas are quite possible and it would result in disappearing of motivation.

Arm wrestling technique develops on the base of analysis of content of sportsmen's competition functioning $[3,4,8]$. It implies registration and evolution of basic requirements and rational variants of techniques, considering limbs' positions in space, their trajectories, distribution of opponent's forces. Arm wrestling techniques are rather conservative because they are restricted by rules of competitions and small space of sportsmen's interaction. Increase of general and special fitness, training of sportsmen's individual abilities - all these influence on technique and its elements. With it main mechanism of movements preserves. Formation and development of every sportsman's technique is realized with consideration of his weight-height indicators and strength of main muscular groups. Correct assessment of movements' technique permits for sportsman to use main and auxiliary training exercises in more correct way. Perfection of sportsmen's technical actions shall be continuous and constant (cyclic-evolutional) with increasing of his fitness level [6, 8,9].

For quicker mastering of arm wrestling techniques we offered to use holistic systemic bio-adequate methodic, which was developed under guidance of academician N.V. Maslova [3, 5, 9, 11]. This methodic is a combination of coach's and sportsman's coordinated actions targeted at motivation and activation of holistic and dynamic thought-forms of sport orientation and skills of work with them. Organization of work was built on integral synthesis of evolving physiological, mental, psychic and moral functions of trainees.

Specific features of REAL-methodic:

- Relaxation stages alternated with active stages;

- Against relaxation background there takes place accumulation of information (work of right semisphere). With activation left semi-sphere's functions are trained (logic, analysis, structuralizing of information);

- Calm atmosphere of training results in improvement of psycho-physical parameters of studentssportsmen's self feeling.

Compulsory condition of bio-adequate training is involvement of sensor motor and symbol stage of work with information. Effectiveness of this methodic application to large extent depends on students' motivation, on comfort condition of their nervous system; on presence of mutual trust and positive micro-climate in students' group.

In every training active and relaxation stages of information perceiving and mastering go turn by turn. Active stage implies the following kinds of work $[1,2,7,8,13]$ :

- Discussion of studied problems;

- Personal experience exchange with perceiving of meaning space of the studied questions;

- Oral questioning of students on the studied material.

In relaxation stage the following work shall be done:

- Listening to the studied material and its visualization;

- Listening to musical compositions for creation of positive psycho-emotional background; these compositions shall differ from compositions of active stage;

- Projecting of virtual models of the studied information by switching brain's projective function in work;

- Construction of thought scheme (pattern) of virtual model of the studied information;

- Creation of comfort zone of training process participants' thinking: "coach-students' group", "coachstudent", "student-student". 
Table 1. Stages of work with information as per REAL-methodic (by N.V. Antonenko et al.)

\begin{tabular}{|c|c|c|c|c|}
\hline \multicolumn{2}{|c|}{ Stages of work at training } & \multirow{2}{*}{$\begin{array}{l}\text { Student's psycho- } \\
\text { physiological condition }\end{array}$} & \multirow{2}{*}{$\begin{array}{l}\text { Student's tasks and } \\
\text { actions }\end{array}$} & \multirow{2}{*}{ Task of impact } \\
\hline № & $\begin{array}{l}\text { Description of stage } \\
\text { and its orientation }\end{array}$ & & & \\
\hline 1 & Sensor motor & relaxation & $\begin{array}{l}\text { Listen to information } \\
\text { and visualize it }\end{array}$ & $\begin{array}{l}\text { Introduction of new } \\
\text { material considering } \\
\text { student's personal } \\
\text { experience and } \\
\text { choice }\end{array}$ \\
\hline 2 & Symbol & activity & $\begin{array}{l}\text { Draw symbol, pattern, } \\
\text { information; } \\
\text { discussion of } \\
\text { information }\end{array}$ & $\begin{array}{l}\text { Involve brain's } \\
\text { different centers in } \\
\text { work }\end{array}$ \\
\hline 3 & Logical & relaxation & Listening to text (task) & $\begin{array}{l}\text { Understanding of } \\
\text { information through } \\
\text { logical thinking }\end{array}$ \\
\hline 4 & Linguistic & activity & $\begin{array}{l}\text { Reading the text } \\
\text { (task). Analysis, } \\
\text { translation and etc. }\end{array}$ & $\begin{array}{l}\text { Mastering of } \\
\text { material }\end{array}$ \\
\hline
\end{tabular}

Pattern is reference thought form, filled with complete structuralized information in algorithmic order. On of its important tasks is to switch in operation all channels of perception, basing on personal experience of a trainee or archetypes (stable pictures of unconscious). Image is result and ideal form of reflection of material or ideal object in human mind. It appears on the base and in form of symbols in conditions of practice and cognition.

In work with $1^{\text {st }}$ and $2^{\text {nd }}$ year students we tested REAL-methodic we received positive result. As the basis we took pattern of professional workmanship of T.V. Bondarenko [5], which was used by the author in training of KhNUME students to discipline "Management of professional workability" (fig.1).

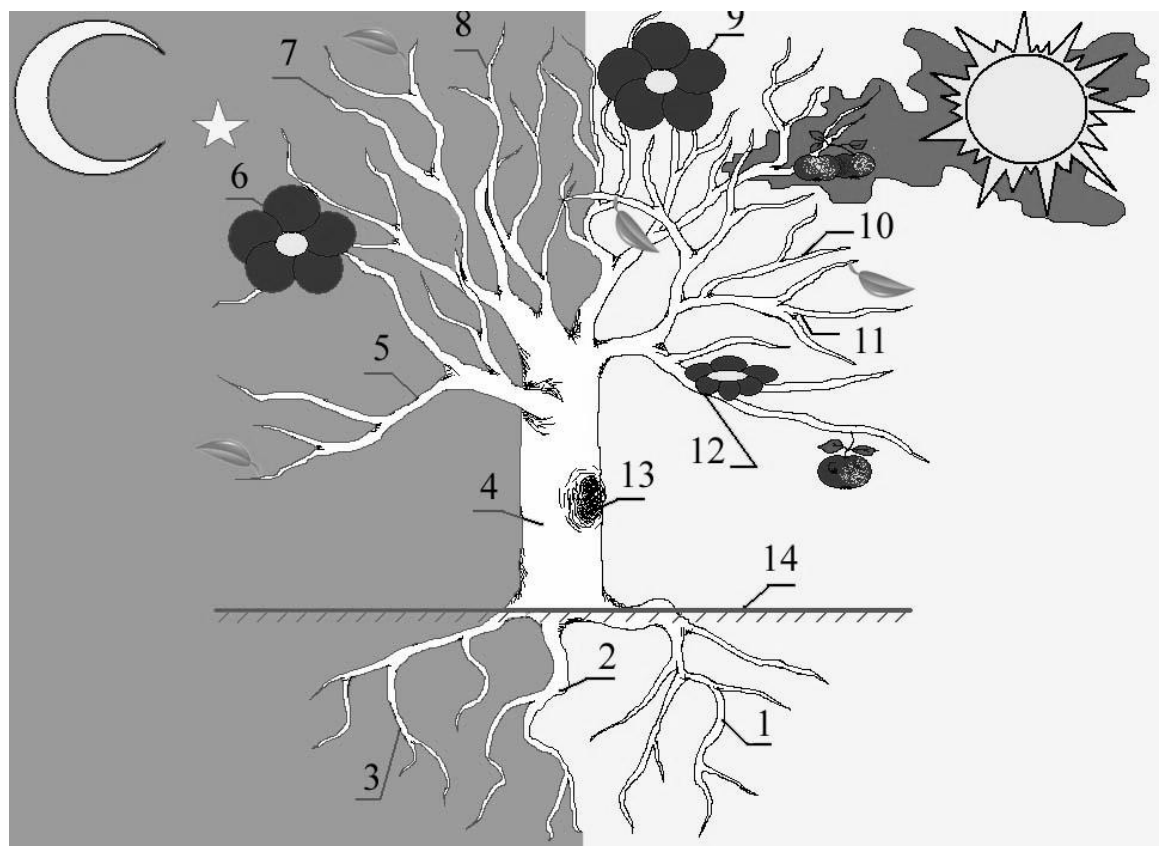

Fig.1. Schema-pattern "Professional functioning of specialist" (by T.V. Bondarenko)

1 - psychic state. 2 - physical health, 3 - social health, 4 - professional workability, 5 - qualification, 6 - labor productivity, 7 - professional fitness, 8 - quality of production, 9 - creative potential, 10 - labor activity, 11 professional ethic, 12 - physiological cost of work, 13 - harmful habits, 14 - professional health. 
In our case tree in the schema is sportsman's personality. The tree's foundation (success in realization of sportsmanship) is single root system (sportsman's health), represented by three branches (physical, psychic and social health). Status of root system (health) conditions vital capacity of tree (sportsman) and depends on ground, on which he lives as well as on many endogenous and exogenous factors, including natural ones (cloud), daily and other biological rhythms (sun-moon). For feeding and strengthening of tree fertile soil is required (sport health). The state and composition of soil influence on growth of the whole tree (height, volume of crown), on its ability to blossom and give fruits (flowers, apples).

The trunk of tree (thought form of sport workability) is the main indicator of progress (sport achievements). Damages of trunk (harmful habits) significantly limit harmony of growth and influence on tree's (sportsman) vital capacity in the whole. Sportsmanship is tree's crown, which can have different volume. As it is known there is close connection between crown (sportsmanship) and root system (health): on surface of ground their area is approximately equal. Crown consists of combination of branches) components of sportsmanship: qualification, efficiency, activity, sport ethic and so on), on which (as indicator of sport functioning's quality) beautiful flowers (realization of sport functioning, creative potential) bloom or not bloom. If technology of wood care (sport regiment) violates physiological laws, the flowers can be flawed (invested funds do not justify result) and fruits (results in money or other form) will be wormy or not appear at all.

\section{Discussion}

Organization of training process in arm wrestling requires consideration of many factors, which characterize personality of sportsman and his coach [18-24]. Prevention of sportsmen from traumatism is especially important. All these taken together determine success of sportsmen's and coach's actions.

The results, received by us, confirm the opinion of many other authors $[5,6,8-11,17]$ about effectiveness of REAL-methodic application in education and physical culture-sport activity. The researches by N.V. Maslova et al. [15] confirm urgency and effectiveness of this methodic usage for economy of human thinking and improvement of health. The authors think that structuralizing of academic information as per principle of gold proportions is a preventive measure in solution of pedagogic task of health protection.

The offered by us methodic is based on combination of coach's and sportsman's coordinated actions. The main direction of such interaction is motivation and activation of holistic thought forms of sport orientation and skills of technological work with them. In training process important role is played by integral preparation, the basis of which is synthesis of physiological, mental, psychic and moral functions of sportsmen. Especial importance has thought pattern of sport workability. This thought pattern is the main indicator of sport achievements. Such approach to construction of training process permits to more effectively control sportsmen's actions.

\section{Conclusions:}

Application of REAL-methodic at initial stage of students-sportsmen's training in arm wrestling gave positive result, accelerated perceiving of trainings' technologies and arm wrestling techniques, shortened period of techniques' mastering and permitted to quicker pass to preparatory basic stage of sport training.

It is noted that 23 from 25 students-sportsmen accurately fulfilled two main arm wrestling techniques: attack over top and attack in hook; two sportsmen made little mistakes in attacking techniques.

Further researches will be oriented on application of REAL-methodic on stages of basic training and direct, pre-competitions' training. For assessment of this methodic it is planned to use special tool methods of students' health assessment.

\section{Acknowledgement}

The research has been fulfilled as per combined plan of scientific-research works in sphere of physical culture and sports for 2011-2015 by topic 3.7 "Methodological and organizational-methodic principles of determination of human physical condition's individual norm" (state registration number 0111U000192).

Conflict of interests

The author declares that here is no conflict of interests. 


\section{References:}

1. Antonenko NV, Ul'ianova MV. Pedagogika noosfernogo razvitiia [Pedagogic of noosphere development]. Moscow: Ekon-Inform; 2007. (in Russian)

2. Astaf'ev BA. Osnovy Mirozdaniia [The foundations of the Universe]. Moscow: White Alva; 2002. (in Russian)

3. Bezkorovajnij DO. Navchannia tekhnici borot'bi na rukakh [Training of arm wrestling technique]. Kharkiv: HNAMG; 2009. (in Ukrainian)

4. Bezkorovajnij DO. Bazova sistema trenuvannia ta sistema bezposeredn'oi pidgotovki do zmagan' v armsporti [Basic system of training and system of directpre-competitions' training in arm wrestling]. Pedagogics, psychology, medical-biological problems of physical training and sports, 2010;1:13-16 (in Ukrainian)

5. Bondarenko TV, Zazdravnov AP, Panina EL. Noosfernoe myshlenie [Noosphere thinking]. Kharkov: SPD District Brovin; 2012. (in Russian)

6. Zavidivs'ka NN. Noosferna pedagogichna paradigma iak konceptual'na osnova fundamentalizacii fizkul'turno-ozdorovchoi osviti studentiv [Noosphere pedagogic paradigm as conceptual basic of fundamentalization of students' health related physical culture education]. Pedagogics, psychology, medicalbiological problems of physical training and sports, 2012;1:68-71. (in Ukrainian)

7. Zviaginceva IM. Silova ta fizichna pidgotovka [Power and physical training], Kharkiv: HNAMG; 2009. (in Ukrainian)

8. Klochko VM, Bezkorovajnij DO. Sportivni iedinoborstva [Sport martial arts], Kharkiv: HNAMG; 2005. (in Ukrainian)

9. Klochko VM. Innovacijni pedagogichni tekhnologii formuvannia psikhofizichnikh i shvidkisno-silovikh iakostej iedinoborciv [Innovative pedagogic technologies of formation of martial arts sportsmen's psychophysical and speed-power qualities], Kharkiv: HNAMG; 2012. (in Ukrainian)

10. Klochko VM. Ocenka zdorov'ia studentov [Assessment of students' health], Kharkiv: HNAMG; 2012. (in Russian)

11. Klochko VM, Bondarenko TV. Primenenie bioadekvatnykh metodik fizicheskogo vospitaniia pri formirovanii noosfernogo myshleniia studentov [Application of bio-adequate physical education methodic with formation of students' noosphere thinking]. Noosfernoe obrazovanie v Ukraine, 2008;2:119-125. (in Russian)

12. Maslova VN. Noosfernoe obrazovanie [Noorsphere education], Moscow: Institute Holodinamiki; 2002. (in Russian)

13. Maslova NV. Noosfernoe obrazovanie [Noorsphere education], XXI Mezhdunarodnaia nauchnaia prakticheskaia konferenciia "Noosfernoe obrazovanie - fundament ustojchivogo razvitiia obshchestva", Sevastopol' [21st International scientific practical conference "Noosphere education - as foundation of society's stable development', Sevastopol], 2007. P.30-50. (in Russian)

14. Maslova NV. Periodicheskaia sistema obshchikh zakonov poznaniia i postizheniia [Periodic system of general laws of cognition and comprehension], Moscow: Institute Holodinamiki; 2007. (in Russian)

15. Maslova NV, Antonenko NV, Ul'ianova MV, Kulikova NG, Mazurina LV, Klyshko ZhM, Vancian IE. Bioadekvatnaia metodika prepodavaniia [Bio-adequate methodic of teaching], Moscow: Center of Natural Sciences "Planet Seven-I."; 2008. (in Russian)

16. Necheporenko LS. Ontopedagogika ta invajromental'na pedagogika [Onto-pedagogic and environmental pedagogic], Kharkiv; 2001.(in Ukrainian)

17. Olejnik NA, Bondarenko TV, Zajcev VP, Kramskoj SI. Invajromental'naia napravlennost' fizicheskogo vospitaniia i ego mesto $\mathrm{v}$ sisteme noosfernogo obrazovaniia [Environmental orientation of physical education and its place in system of noosphere education]. Physical education of students of creative specialties, 2008;3:83-93. (in Russian)

18. Dragnev YV. General not specialized subject armsport in conditions of profile training within the framework of base general not specialized subject physical culture. Pedagogics, psychology, medical-biological problems of physical training and sports. 2009;10:51 - 53.

19. Kamaev OI, Bezkorovainyi DO. Influence of the experimental program of trainings in armsport on the power indexes of basic muscle groups of 16-17-years-old armwrestlers. Pedagogics, psychology, medicalbiological problems of physical training and sports, 2013;1:34-39. http://doi.org/10.6084/m9.figshare.106936

20. Podrigalo LV, Galashko MN, Galashko NI. Study and evaluation of indicators of relationships motor analyzer sportsmen of armsport. Physical Education of Students, 2013;3:46-49. http://doi.org/10.6084/m9.figshare.669671

21. Podrigalo LV, Galashko MN, Galashko NI, Prusik Krzysztof, Cieślicka Mirosława. Research of hands' strength and endurance indications of arm sport athletes having different levels of skills. Physical education of students, 2014;2:37-40. http://doi.org/10.6084/m9.figshare.907140 
22. Podrigalo LV, Galashko NI, Galashko MN. Goniometric researches of armwrestling sportsmen. Physical Education of Students, 2013;1:45-49. http://doi.org/10.6084/m9.figshare.156357

23. Podrigalo LV, Galashko NI, Galashko MN. Using ergonomic approaches for increasing effect of preparation at arm sport. Physical Education of Students, 2012;1:87-90.

24. Podrigalo LV, Iermakov SS, Nosko MO, Galashko MN, Galashko NI. Study and analysis of armwrestlers' forearm muscles' strength. Journal of Physical Education and Sport, 2015;15(3):531-537. 
Information about the author:

Bezkorovainyi D.O.; http://orcid.org/0000-0003-1437-2932;

bezkor@ua.fm; Kharkiv National University of Municipal Economy; Revolution str. 12, Kharkov, 61000, Ukraine.

Cite this article as: Bezkorovainyi D.O. Application of REAL-methodic for mastering arm wrestling techniques. Physical education of students, 2015;5:9-15. http://dx.doi.org/10.15561/20755279.2015.0502

The electronic version of this article is the complete one and can be found online at: http://www.sportpedu.org.ua/html/arhive-e.html

This is an Open Access article distributed under the terms of the Creative Commons Attribution License, which permits unrestricted use, distribution, and reproduction in any medium, provided the original work is properly cited (http://creativecommons.org/licenses/by/4.0/deed.en).

Received: 16.08 .2015

Accepted: 29.08.2015; Published: 02.09.2015 